\title{
Geopolitics of Knowledge and Cultural Displacements
}

\author{
Florent VILLARD
}

Translator. Gregory LEE

\section{OpenEdition}

Journals

\section{Electronic version}

URL: http://journals.openedition.org/transtexts/564

DOI: $10.4000 /$ transtexts.564

ISSN: 2105-2549

\section{Publisher}

Gregory B. Lee

\section{Electronic reference}

Florent VILLARD, "Geopolitics of Knowledge and Cultural Displacements », Transtext(e)s Transcultures 跨文本跨文化 [Online], 9 | 2014, Online since 16 October 2015, connection on 19 April 2019. URL http://journals.openedition.org/transtexts/564 ; DOI : 10.4000/transtexts.564

\section{This text was automatically generated on 19 April 2019}

() Tous droits réservés 


\section{Geopolitics of Knowledge and Cultural Displacements}

Florent VILLARD

Translation : Gregory LEE

\section{The Lyon's Institut Franco-chinois: the politicization of memory}

1 The writing of history is always an intervention from and in the present. We publish this thematic issue in the context of a spectacular eruption of Lyon's Institut Franco-chinois ( 中法大學 or Sino-French University) onto the public stage.

2 Neglected over several decades after its official closure in 1946, the fecund and instructive history of the Institute re-surfaced, a decade ago, when the City of Lyon decided to valorize this under-exploited cultural capital. A small memorial museum was established in the former premises of the Institute and an exhibition narrating the story of the Institute was displayed in the Rhône-Alpes regional pavilion during the World Expo, or rather 'Expo 2010 Shanghai China' as it was formally called. Until the month of March 2014, this Sino-French heritage served as a marketing attraction intended to draw Chinese tourists and investors to Lyon. Indeed, in the context of the redefinition of the city of Lyon, now envisaged as a brand whose image had to be sold, the Institute could reasonably be expected to serve as the historical underpinning of a new metropolitan story anchoring Lyon in the imaginary of globalization.

But this contemporary instrumentalization of the Institute shifted onto on a higher and vaster plane at the moment of the state visit of the President of the People's Republic of China Mr. Xi Jinxing in March 2014. Thereafter, the hitherto local heritage and marketing potential of the Institute was supplanted by Chinese internal political considerations. The Presidential visit heralded a displacement of perspective and a recuperation of the memory of the site. The language employed by China's media framed the visit as a return to the origins of the Chinese Communist Party and, ignoring historical reality, foregrounded the presence in Lyon of the legendary Chinese Communist leaders Zhou 
Enlai 周恩来 et Deng Xiaoping 邓小平. At the same time the history of more controversial CCP figures, such as the celebrated activist and former PRC minister Li Lisan 李立三 who is documented as being present in Lyon to demand a democratization of the Institute, was ignored by the Chinese press. What in fact took place was a 'commemorative' show aimed at writing the story of the Institute into the official history of Peking's one-party state.

This contemporary political instrumentalization of the Institute also reminds us to be on our guard concerning the preservation of the material traces of this history constituted by the archives of the Institute. Held at the Lyon Municipal Library, the archives of the former Association franco-chinoise de Lyon (which provided the legal framework of the Institute) belong to the Jean Moulin University in Lyon. It consists of administratives records detailing the social, cultural and academic lives of the 473 students who passed through the Institute's doors, plus 25,000 monographs and 500 periodicals originating from the former Institute's library. This library, constituted by, and for Chinese students between 1921 and 1946 represents a unique documentary resource for specialists of the cultural history of modern China.

If these contributions to this issue of Transtext(e)Transcultures are appearing at a time of intense and dubious commemorative activity, the reflection contained in these articles relate to another level of concern, and to a different time.

6 In 2015, China is on the verge of becoming the world's supreme power. It is gradually but surely becoming dominant. But it is being left in charge of turning the handle of barrel organ whose music was determined more than two centuries ago in Europe. ${ }^{1}$ China has progressively and painfully appropriated the language and the practices of a Eurocentric modernity: science-become-technology, the supposedly 'rational' domination of Nature and human activity, capitalism and its associated Nation-state institutions.

7 A school for modernity, the Institute was also an exemplary laboratory in this learning process, a site of self-colonization in terms of knowledge and culture for the use of China's elite. It should be stated that contrary to the conviction of those involved in this project at the time, this experiment was in no sense the result of an historically necessary and inevitable stage of China's development. It was rather one element in a political and ideological project. French authorities wished for French science, culture and values to be propagated in a country already seen as a potentially important market. Nevertheless, it is beyond doubt that the intellectuals of the Fourth of May Period, convinced by the ideologies of both nationalism and science, actively participated in this project aimed at 'modernizing' Chinese society. ${ }^{2}$ Former anarchists and fervent republicans, the prime Chinese proponents of the IFCL, including Cai Yuanpei 蔡元培 and Li Shizeng 李石曾, had also subscribed to the political dimension of modernity during the long periods of time they had spent in Europe. They were inspired by the project of political autonomy that emerged at the time of the French Revolution. They supported the need for modern societies to institute themselves, rather than be the mere product of colonialism. Alongside Mr Science (Sai xiansheng 赛先生), they promoted Mr Democracy (De xiansheng 德先生). This progressive heritage of modernity is downplayed today in China by those responsible for (re)writing history from the point of view of the victors, that is the bureaucratic oligarchy that currently holds power. 


\section{A School for modernity: arts, literature and science}

Following an initial workshop entitled 'Migrations des savoirs, le cas de l'IFCL' [Knowledge migration: The case of the IFCL], which took place in Lyon in January 2012, in 2014 (and 2015) we launched a collaborative project entitled 'Lyon Sino-French Institute Archives: A Cultural and Academic Heritage of Global Modernity in the Age of Digital Humanities' which aimed to render the archive more easily accessible and useful through the process digitization. ${ }^{3}$ We plan to organize, classify and digitize the archives of the former Institut franco-chinois de Lyon (Lyon Sino-French Institute, hereafter IFCL) so as to pose questions relevant to our own research project on the students' social and cultural life, intellectual imaginary and epistemologies, but also so as to create an accessible digital archive that will facilitate further projects aimed at disseminating a broader public acquaintance with this archive. The present special issue constitutes the first collective step of this research.

In the first contribution to this volume, Valentina De Monte, former 'conservatrice,' or keeper, of the Chinese collection of the Lyon Municipal Library, provides a survey of the scope and nature of the Institute's collections. Underlining the unique value of these documents, she tells the history of the collection now housed in the municipal library and discusses the various uses and particularities of the documents. At first sight, their specificity would seem to interest only specialists and scholars. But the public service mission of a national library - the Lyon Municipal Library is one of the country most important libraries outside of Paris - also implies that the collection should be opened up to a wider reading public. Valentina De Monte suggests that this double vocation of research and accessibility to a wider public should be taken into account in any forthcoming digitization project.

In discussing the events that became known as the 'Lyon March,' Gregory Lee the fractious lead-up to the inauguration of the Institute in the autumn of 1921. The Chinese intellectual elite imagined the Institute as an alternative to the 'work-study' programme which had been initiated by Li Shizeng in 1909. The programme which aimed to enable Chinese students to finance their studies by working in French factories, expanded considerably at the end of World War One, only to fall victim to the 1921 economic crisis which led to the laying-off of many of the worker-students. Faced with unemployment and dwindling funds, the worker-students saw the opening of the Institute in September 1921 as a solution to their predicament and as a means of pursuing their studies in more comfortable and dignified conditions. But the Institute had not been conceived for them. It was meant to enroll suitably financed students who had been selected and trained in China, and whose commitment was to knowledge rather than political activism. Making use of archival government, police and other archival material, Gregory Lee tells the story of the incidents collectively known as the 'Lyon March' from the point of view the French authorities, but also, based on the students' individual and collective appeals to be allowed to stay in France, recounts the students' version of their demands and their outcome. He narrates with surgical precision the events which led first to the detention and ultimately to the expulsion from France of over a hundred students deemed unworthy of passing through the portals of the new Sino-French University, and yet who had dared to contest the enrollment policy of the Institute 
11 The contributions of Wang Yiyan and Jacqueline Estran demonstrate that the IFCL experiment was also of great importance in the evolution of China's literary and artistic creativity with several Institute graduates becoming celebrated writers and artists. Wang Yiyan's contribution recounts the as yet untold story of Lyon's role in the making of Chinese twentieth-century art. She demonstrates the influence of French art schools, and in particular the National Fine Art School in Lyon (l'Ecole Nationale des Beaux-Arts de Lyon or ENBAL), in the training of Chinese artists and in the constituting of a body of Chinese national modern art. Wang Yiyan's meticulous research in Lyon in both the archives of the Institute and of the School of Fine Art, results in the restitution of the achievements and creative production of the most talented of students such as Wang Jingyuan 王靜遠, Pan Yuliang 潘玉良, Chen Zhixiu 陳芝秀, Fang Yun 方藴, Chang Shuhong 常書鴻, Lü Sibai 吕斯百, and Wang Linyi 王臨乙; artists who would play a major role in aesthetic and artistic education in China. Wang Yiyan thus reminds us that the modernisation project of the 4th May intellectuals, and notably of Institute founder Cai Yuanpei, was not limited to the project's techno-scientific and political dimensions, but also included the aesthetic domain.

Jacqueline Estran approaches the history of the Institute from the perspective of gender, underlining a remarkable aspect of this institution and what was a marker of its modernity: the presence of several dozen women students of whom a significant number obtained a doctorate. Estran's article sheds light on both the geographic and social origins of these students. She also informs us about the academic achievements of Luo Zhenying 羅振英, Lin Baoquan 林寶權, Wu Xuxin 吳續新 and Liang Daozhen 梁導貞, all doctoral graduates of the Institute. In the second part of her article, Estran offers a unique analytical insight into the life of Su Xuelin 蘇雪林, graduate of the IFCL, who would go on to become major figure in the world of modern Chinese literary creation. Through Su's texts, and via her autobiography, Jacqueline Estran exposes the complexity of the intellectual career of this writer and the crucial role her time in Lyon played in the evolution of her life.

13 The contributions of Marie-Julie Maitre and Liang Hongling address the IFCL in a larger context of the modernist moment and focus on the geopolitics of knowledge, the migration of ideas and historiographic interrogations of Eurocentrism. In her article on the geopolitics of knowledge and philosophy in the context of the Institute, Marie-Julie Maitre, through a theoretical prism that draws on the theses of Edward Said and Walter Mignolo, offers us an audacious analysis of the doctoral dissertations of the philosophy students at the Institute from the perspective of colonial geopolitics of knowledge. She questions the status of Chinese philosophy in the context of epistemological dominance of the West, while ensuring that this category is not reduced to a mere a cultural definition. Liang Hongling extends this reflection emphasizing the effacement of the colonial context in which policies of 'cooperation' and 'mutual assistance' were instituted in the educational domain at the end of the nineteenth century. To illustrate her point, she examines the politico-cultural uses to which the Boxer Indemnity were put, and compares the American and French educational programmes on offer to Chinese students at that time. The essay puts into an international perspective the IFCL experiment. 


\section{Varia: François Jullien, transcultural critique and the transnational issue of « overcoming modernity »}

14 By the sheer volume of his work, the singularity of his philosophical approach and also his pedagogical talent, Francois Jullien, has become an inevitable reference whenever the question of Chinese intellectual history is compared with Europe's. In the humanities in France and elsewhere numerous are those who greatly appreciate his enterprise of rereading the Western philosophical tradition through the prism of 'Chinese thought'. In response to the strident monograph by Jean François Billeter (Contre François Jullien [Against François Jullien] (Allia 2006), the author of Procès et création [Process and creation] vigorously defended himself denying having given an essentialist reading of China and its intercultural relations, and appealing for a constructivist approach to difference beyond dominant culturalist thinking.

In an article hitherto unpublished in French, Fabian Heubel delves into the question of Jullien's comparativism and his take on cultural difference. ${ }^{4} \mathrm{He}$ proposes a transcultural critique of Jullien's work from the standpoint of another historical a priori, that of modernizaton as a 'shared, common problem'. Fabian Heubel reminds us that Jullien's methodological approach only becomes possible if we elide modern social and historical realities. By assuming that a relative homogeneity existed in China's imperial elite, high culture and in postulating an intrinsic cultural and philosophical continuity between ancient Greece and Enlightenment Europe, two already contestable historical a priori, the methodological hypothesis of externality of the 'Chinese text' seems effectively plausible. But in that case we should need to remove China's modern experience of modernity from our reading of today's world, ignoring the phenomena of circulation and hybridity inherent in the postcolonial condition of modern times. Heubel contests the concept of the cogitative 'écart' or gulf proposed by Jullien, and by taking seriously 'modern and contemporary sinogrammatic philosophy' in its hybrid and transcultural dimensions, he anticipates, and calls for, a sinification of European philosophy.

In his provocating paper entitled "The syndrom of overcoming modernity: learning from Japan about ultra-nationalism", Alain-Marc Rieu deals with Japanese nationalism in the twentieth century in a comparative perspective. The intellectual attempts to 'go beyond modernity' that were made in 1930s Japan constitute Alain-Marc Rieu's point of departure. But the author does more than merely analyse the proceedings of the 1942 'infamous conference' in Tokyo, he questions the radicalness of this critique of modernity by eschewing the specificity of the Japanese context to envisage this 'meta-ideology' of the 'surpassing of modernity' as a 'syndrome of a singular and dangerous moment in the modernizations of human societies.' Rieu reminds us that forms of societal disenchantment with modernity, which anchored relations between the contemporary to the mythic past and prosed an ahistorical vision of national communities, also arose in Germany and France. And yet Japan's experience of fascism, its ideological, social and psychological impulses, should also illuminate political and discursive phenomena currently surfacing in certain contemporary, especially 'non'Western,' societies such as Russia and China which conceive Europe as a 'counter-example'. These current ideological tendencies suggest an ambiguous and dangerous alternative modernity which would preserve a certain transcendence and invent a mythic continuity continuing a tradition and possessing pre-modern 'roots.' 


\section{NOTES}

1. Gregory Lee, «Le cadeau empoisonné de Versailles ou la Chine à la manivelle de l'orgue de barbarie ", Mouvements, 2012, 4, n72 (page consulted on 10/03/2014 url: http:// www.cairn.info/resume.php?ID_ARTICLE=MOUV_072_0079 ) and see Lee's forthcoming iBook China's Dreaming, 2015.

2. On 4th May 1919 students and other progressive forces, learning that China had been badly treated in the Versailles Peace Treaty, demonstrated at Tiananmen Square. China had participated in World War One along side the British, French and Americans, for instance in supplying tens of thousands of men to the British Army's Chinese Labour Corps to dig war trenches, and yet the vanquished Germans' possessions and economic rights in China were not returned to China but rather transferred to Japan. The demonstration's twin slogan favouring 'Democracy' and 'Science', encapsulated the Fourth of May Movement's aims which were to use Western knowledge and methods to (re)gain Chinese sovereignty over its own soil.

3. The presentation of this research project is available on the following webpage: www.http//:ifcl.bid (page consulted on 02/10/2015).

4. This contribution is followed by a short reply by François Jullien. 